\title{
Low Resting Potential and Postnatal Upregulation of NMDA Receptors May Cause Cajal-Retzius Cell Death
}

\author{
Jean-Marc Mienville and Christine Pesold \\ The Psychiatric Institute, Department of Psychiatry, The University of Illinois at Chicago, Chicago, Illinois 60612
}

\begin{abstract}
Using in situ patch-clamp techniques in rat telencephalic slices, we have followed resting potential (RP) properties and the functional expression of NMDA receptors in neocortical CajalRetzius (CR) cells from embryonic day 18 to postnatal day 13, the time around which these cells normally disappear. We find that throughout their lives $\mathrm{CR}$ cells have a relatively depolarized $\mathrm{RP}$ (approximately $-50 \mathrm{mV}$ ), which can be made more hyperpolarized (approximately $-70 \mathrm{mV}$ ) by stimulation of the $\mathrm{Na} / \mathrm{K}$ pump with intracellular ATP. The NMDA receptors of CR cells are subjected to intense postnatal upregulation, but their similar properties $\left(\mathrm{EC}_{50}\right.$, Hill number, sensitivity to antagonists, conductance, and kinetics) throughout development suggest that
\end{abstract}

A peculiar feature of NMDA receptors is their ambivalent role in brain function. On the one hand, their timely activation is required for the proper maturation of neuronal circuits, but they also appear to be involved in cellular death in certain pathological states (for review, see McDonald and Johnston, 1990). More importantly, in both cases the same transduction mechanism, namely an increase in intracellular $\mathrm{Ca}^{2+}\left(\left[\mathrm{Ca}^{2+}\right]_{i}\right)$, appears to be operative. This suggests that there may be an optimal $\left[\mathrm{Ca}^{2+}\right]_{\mathrm{i}}$ level-and hence an optimal NMDA receptor activation-beyond which beneficial effects are replaced by uncontrolled processes that trigger cell lysis. In view of the membrane potential $\left(V_{\mathrm{m}}\right)$ dependence of NMDA receptor activation whereby depolarization is needed to remove the $\mathrm{Mg}^{2+}$ blockade of the associated channel (Mayer et al., 1984; Nowak et al., 1984), a plausible working hypothesis is that different resting potential (RP) levels dictate the fate of neurons exposed to the natural agonist(s), most likely glutamate or aspartate, of NMDA receptors present on their membranes.

Brain development is characterized by alternating phases of massive neurogenesis and neuronal death as well as of intense synaptogenesis and synaptic pruning. Currently, a large research effort is devoted to the study of apoptotic mechanisms, which likely mediate the large-scale neuronal elimination that occurs during the development of most brain structures (Oppenheim, 1991). A special cell population found in the immature cortex of most mammals, the Cajal-Retzius (CR) neurons (Ramón y Cajal, 1891), also appears to be subjected to elimination. The disappearance of these cells around the end of the second week

Received Aug. 20, 1998; revised Nov. 30, 1998; accepted Dec. 16, 1998.

We are grateful to Dr. André Goffinet for his generous gift of G10 antibody, to Dr. John Dempster for help with noise analysis, and to Dr. Erminio Costa for stimulating discussions during the course of this work.

Correspondence should be addressed to Dr. Jean-Marc Mienville, The Psychiatric Institute, Department of Psychiatry, The University of Illinois at Chicago, 1601 West Taylor Street, m/c 912, Chicago, IL 60612.

Copyright (C) 1999 Society for Neuroscience $\quad 0270-6474 / 99 / 191636-11 \$ 05.00 / 0$ their subunit composition remains relatively homogeneous. The low RP of CR cells is within a range that allows for the relief of NMDA channels from $\mathrm{Mg}^{2+}$ blockade. Our findings are consistent with the hypothesis that CR cells may degenerate and die subsequent to uncontrolled overload of intracellular $\mathrm{Ca}^{2+}$ via NMDA receptor activation by ambient glutamate. In support of this hypothesis we have obtained evidence showing the protection of CR cells via in vivo blockade of NMDA receptors with dizocilpine.

Key words: Cajal-Retzius cell; cell death; NMDA receptor; resting potential; patch clamp; brain slice postnatal in rodents is, however, a matter of controversy, being attributed to "dilution" in a rapidly expanding cortex, transformation into another cell type, or necrotic degeneration and death (for review, see Marín-Padilla, 1998). The latter alternative recently has received strong experimental support (Derer and Derer, 1990, 1992; Del Río et al., 1996). These considerations are relevant to the view that "natural" or "developmental" cell death might be triggered by a combination of genetic and epigenetic factors (Oppenheim, 1991). In this perspective the classical assimilation of excitotoxicity and necrosis to pathological cell death (Choi, 1988) may have to be revised to include physiological cell death. For example, the differential survival of CR cells in vitro versus in vivo suggests that extrinsic factors, such as glutamate, might be responsible for their destruction (Derer and Derer, 1992; Del Río et al., 1996). The combination of factors alluded to above then may provide tentative explanations as to why only a specific cell population, among the multitude of cells exposed to the action of glutamate, would be particularly vulnerable. For instance, McDonald and Johnston (1990) have reviewed evidence that energy depletion and its possible consequences on ionic pump failure may contribute to excitotoxicity. Here, we propose the hypothesis that a low resting potential, which indeed might be attributable to pump failure, and a dramatic postnatal increase in functional expression of NMDA receptors may combine to precipitate CR cell death.

Given the prominent developmental role that CR cells play in neuronal migration and cortical lamination (Rakic and Caviness, 1995), it seems important to pursue a systematic investigation of their physiological properties. Thus we also have achieved a relatively detailed characterization of the NMDA receptor present in these cells during embryonic and postnatal stages. Another important consideration is the common belief that these pioneer neurons, which are born early [embryonic day (E) 12-13 in the rat], also mature early (Jacobson, 1991). Contrary to that view, previous reports (Zhou and Hablitz, 1996; Mienville and 
Barker, 1997; Mienville, 1998b), along with the present paper, indicate that several membrane properties of CR cells mature both prenatally and postnatally, suggesting that the demise of these cells may not be a mere accident during the course of their existence.

Part of this work has appeared in abstract form (Mienville, 1998a).

\section{MATERIALS AND METHODS}

Preparation of slices for electrophysiology. Experiments were performed with in situ patch-clamp techniques (Edwards et al., 1989) as previously described in detail (Mienville and Barker, 1997; Mienville, 1998b). Briefly, 300- $\mu$ m-thick coronal slices of intermediate cortex were obtained from E18 and postnatal day (P) 5 and P11-P13 Fisher rats and were stored in a medium consisting of (in $\mathrm{mM}$ ) $120 \mathrm{NaCl}, 5 \mathrm{KCl}, 1.25$ $\mathrm{NaH}_{2} \mathrm{PO}_{4}, 2 \mathrm{MgCl}_{2}, 2 \mathrm{CaCl}_{2}, 26 \mathrm{NaHCO}_{3}, 1 \mathrm{Na}$ pyruvate, and 10 dextrose. This medium was supplemented with essential amino acids and MEM vitamins (Life Technologies, Rockville, MD) and bubbled with $95 \% \mathrm{O}_{2} / 5 \% \mathrm{CO}_{2}$ to yield a $\mathrm{pH}$ of 7.4. The same medium was used to superfuse slices continuously $(0.5 \mathrm{ml} / \mathrm{min})$ during patch-clamp recordings, except for most experiments on NMDA-mediated currents, in which case, unless otherwise noted, $\mathrm{MgCl}_{2}$ was omitted and $10 \mu \mathrm{M}$ glycine was added.

CR cells were identified under Hoffman modulation contrast optics on the basis of three morphological criteria: (1) their location on the external border of Layer I; (2) fusiform or ovoid, mostly bipolar morphology; (3) somatic and neuritic horizontal orientation (Ramón y Cajal, 1891; Huntley and Jones, 1990; Zhou and Hablitz, 1996; Mienville and Barker, 1997) (see Fig. 8). A secondary criterion was the fact that cells with the above features had a relatively high input resistance, higher, for example, than both Layer II pyramidal neurons and another cell typepresumably neurogliaform - present in Layer I (Mienville, 1998b). Furthermore, cells that satisfy these morphological criteria virtually disappeared by P13, as expected from rodent CR cells (Derer and Derer, 1990, 1992; Del Río et al., 1995, 1996; Hestrin and Armstrong, 1996).

Drug application and patch-clamp recording. The drug application apparatus consisted of an eight-line bundle connected to three-way solenoid valves (Neptune Research, West Caldwell, NJ) fed by a peristaltic pump and converging onto a $100-\mu \mathrm{m}$-diameter (inner diameter) micromanifold (ALA Scientific Instruments, Westbury, NY). The valves were controlled by a ValveLink- 8 driver (AutoMate Scientific, Oakland, CA), allowing for short applications of agonists to be synchronized with data acquisition via the digital outputs of a Digidata 1200B interface and the CLAMPEX module of pClamp6 software (Axon Instruments, Foster City, CA). The speed limitations of our system, which are related mainly to the diffusional barrier intrinsic to the slice preparation, have been discussed previously (Mienville, 1998b).

Pipette solutions contained either KCl plus K-gluconate (10 plus 137 $\mathrm{mm})$ or $\mathrm{CsCl}(147 \mathrm{~mm})$ as main salts. These solutions were buffered with HEPES (10 mM) and an appropriate amount of $\mathrm{KOH}$ or $\mathrm{CsOH}$ to yield a $\mathrm{pH}$ of 7.2. A $10 \mathrm{mV}$ junction potential was taken into account when K-gluconate pipettes were used. For some experiments, $10 \mathrm{~mm}$ EGTA or $4 \mathrm{~mm}$ Mg-ATP plus $10 \mathrm{~mm}$ phosphocreatine was added to the K-gluconate solution, in which cases osmolarity and $\mathrm{pH}$ were corrected accordingly. Perforated-patch experiments were performed as previously described (Mienville, 1998b), with electrodes prefilled with regular solution and backfilled with the same solution containing $50 \mu \mathrm{g} / \mathrm{ml}$ gramicidin.

Whole-cell voltage-clamp and current-clamp signals were amplified with a List EPC7 unit (List Electronic, Darmstadt, Germany). Most clamp currents were sampled on-line and later analyzed with pClamp6. Voltage-clamp recordings destined to noise analysis, as well as currentclamp recordings, were stored on video tape via an Instrutech VR100B unit (Great Neck, NY; bandwidth DC-37 kHz). Cell capacitance was measured as previously described (Mienville and Barker, 1997).

Noise analysis. Currents activated by $100 \mu \mathrm{M}$ NMDA at $V_{\mathrm{m}}=-60 \mathrm{mV}$ were high-pass-filtered at $5 \mathrm{~Hz}$, low-pass-filtered at $10 \mathrm{kHz}$, and sampled at $20 \mathrm{kHz}$. At this high bandwidth, given the small amplitude of the currents recorded at E18, a $100 \mu \mathrm{M}$ concentration of agonist was a necessary compromise to yield a suitable signal-to-noise ratio. The SPAN module of SES software (John Dempster, University of Strathclyde, UK) was used for acquisition and analysis. Traces $10-15 \mathrm{sec}$ long and containing baseline noise were collected mostly as 4096 point records. Baseline noise was subtracted from all plots. Single-channel conductance $(\gamma)$ was determined from variance $\left(\sigma^{2}\right)$ versus mean current ( $I$ ) plots fit with either a linear or parabolic curve of the form: $\sigma^{2}=i I-$ $\left(I^{2} / n\right)$, where $i=$ unitary current and $n=$ the number of channels. Conductance then was obtained by dividing $i$ by a $60 \mathrm{mV}$ driving force, assuming a reversal potential of $0 \mathrm{mV}$ (see Fig. 5). Linear fits generally were used for currents recorded at E18, whereas postnatal data appeared more amenable to parabolic fitting. This is probably attributable to the fact that currents recorded in postnatal cells were larger and showed more gradation in their time course, which allowed for larger open probability $\left(P_{\mathrm{o}}\right)$ ranges to be included in the plots (note that $\left.I=i n P_{\mathrm{o}}\right)$. Conductance values obtained by linear fitting of E18 data were in good agreement with those obtained from spectral analysis (2.6\% difference). In contrast, postnatal spectra generally underestimated $\gamma(11 \%$ at P5 and $16 \%$ at $\mathrm{P} 12)$, probably because of high $P_{\mathrm{o}}$. Nevertheless, $\gamma$ estimated by variance analysis was lower than expected from single-channel data [normally 40-50 pS; see, however, LoTurco et al. (1991)]. The same discrepancy obtained with noise analysis already has been reported by others (Mayer et al., 1988). It could be attributable to a variety of factors, including the presence of subconductance states, unclamped neuronal processes, and bandwidth limitations (Heinemann and Conti, 1992).

Spectral analysis was performed on steady-state currents after the exclusion of onset records (see Fig. 6). Power spectra were fit with a Lorentzian function, $S(f)$, of the form: $S(f)=S(0) /(1+f / f c)$, where $S(0)$ is the spectral density at zero frequency $(f)$, and $f c$ is the cutoff frequency corresponding to $S(0) / 2$. The time constant $(\tau)$ of channel gating was calculated as $(2 \pi f c)^{-1}$. For the rare cases in which spectra decayed with more that one component, the faster component, which displayed great variability, was not considered further. For each cell, two to four measurements of both $\gamma$ and $\tau$ were averaged.

Dizocilpine treatment protocols. Three different dizocilpine treatment protocols were tested. For all protocols, dizocilpine was injected subcutaneously twice daily at 9:00 A.M. and 9:00 P.M. The drug was diluted in a volume of saline solution $(50 \mu \mathrm{l})$ that also was injected to control animals. With the first protocol, in which P8 rat pups were injected with $1 \mathrm{mg} / \mathrm{kg}$ dizocilpine, all treated animals died on the third day. The second protocol started at P9 and used $0.5 \mathrm{mg} / \mathrm{kg}$ dizocilpine. Two treated animals died on the fourth day; the remaining six animals (three controls plus three treated) were killed at P13, and their brains were processed as described below. The third protocol started at P6 and used $0.1 \mathrm{mg} / \mathrm{kg}$ dizocilpine. Two treated animals died on the fourth day, and one died on the sixth day; the remaining eight animals (three controls plus five treated) were killed at P20, and their brains were processed as described below.

Immunocytochemistry. Slices from animals treated according to the second protocol were obtained in the same manner as for electrophysiology. After visually identified live CR cells were counted, the slices were placed for $1 \mathrm{hr}$ in fixative (4\% paraformaldehyde in PBS), washed three times, and stored in PBS. Animals treated with the third protocol were anesthetized with $\mathrm{CO}_{2}$ and perfused intracardially with $10 \mathrm{ml}$ of PBS, followed by $10 \mathrm{ml}$ of ice-cold fixative. Brains were removed, left in fixative for $24 \mathrm{hr}$, and embedded in $30 \%$ sucrose in PBS for 2-3 d. Then the brains were frozen, sectioned in a cryostat at $300 \mu \mathrm{m}$, and placed in PBS. All immunostaining was performed on sections free-floating at room temperature, unless otherwise indicated. After a thorough rinsing in TRIS-buffered saline with $0.25 \%$ Triton X-100 (TBST; pH 7.4), sections were blocked with $3 \%$ normal goat serum (NGS) in TBST and incubated for $48 \mathrm{hr}$ at $4^{\circ} \mathrm{C}$ with $\mathrm{G} 10$ antibody (provided by A. Goffinet, Facultés Universitaires Notre-Dame de la Paix, Namur, Belgium) diluted in $1 \%$ NGS in TBST (1:1000). G10 antibody specifically recognizes an epitope close to the $\mathrm{NH}_{2}$ terminus of the Reelin protein (De Bergeyck et al., 1997). After a $2 \mathrm{hr}$ incubation at room temperature the sections were washed several times in 1\% NGS in TBS and were incubated for $1 \mathrm{hr}$ in biotinylated secondary antibody (1:250 in 1\% NGS in TBS). After several TBS rinses the sections were incubated for $1 \mathrm{hr}$ with an avidin-biotin kit (Vector Laboratories, Burlingame, CA), rinsed, and reacted with 3,3'diaminobenzidine containing nickel. Finally, the sections were rinsed and mounted on slides. Sections from protocol number 3 were also counterstained with neutral red cell stain.

Quantification of CR cells. For each pup, cell counts from two to three slices of one hemisphere ("hemislice") of intermediate cortex were averaged. The number of CR cells present was estimated in several ways: first, in live sections by using the three morphological criteria described above; second, in sections that were immunostained for Reelin by counting the number of cells that were immunopositive and that satisfied the 


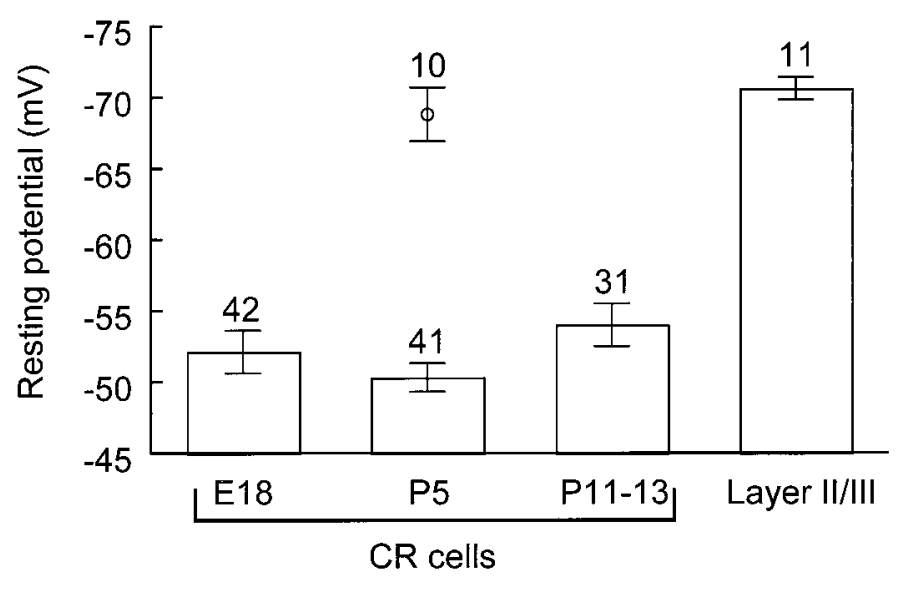

Figure 1. Resting potential in prenatal and postnatal CR cells and in Layer II pyramidal neurons. Resting potential was measured in current clamp after whole-cell access with K-gluconate pipettes. The single marker at $P 5$ corresponds to the value measured $10 \mathrm{~min}$ after currentclamp recording with ATP in the pipette. Excluding this value, there was no significant difference among early and late CR cells $(p=0.19)$, whereas a highly significant difference distinguished CR cells from Layer II cells $\left(p=3 \times 10^{-10} ;\right.$ ANOVA $)$.

three morphological criteria. In the latter case, stereological analysis also was performed by normalizing cell count to the volume of tissue estimated for each section (the width of Layer I was estimated at $100 \mu \mathrm{m}$ ). In live slices from P20 animals (protocol number 3), no CR cells could be identified unambiguously; therefore, only immunostained slices were used.

All drugs were from Sigma (St. Louis, MO) except for [ \pm ]-3-[2carboxypiperazin-4-yl]propyl-1-phosphonic acid (CPP), dizocilpine (Research Biochemicals, Natick, MA), D-AP5, and ifenprodil (Tocris Cookson, Ballwin, MO). Data are expressed as mean \pm SEM. Student's $t$ test and ANOVA were used when two or more than two groups were compared, respectively.

\section{RESULTS}

\section{Resting potential of CR cells}

A consistent feature of CR cells at all ages studied was their relatively low RP. This was in striking contrast with the well polarized RP measured in non-CR cells present in Layer I (data not shown) and with that measured in Layer II pyramidal cells in postnatal cortex (Fig. 1). Only in postnatal CR cells was this low RP often associated with spontaneous firing, i.e., the latter never occurred in E18 CR cells. Spontaneous all-or-none spikes were mainly undershooting (Fig. 2A,C-E), but overshooting spikes were encountered occasionally (Fig. $2 F$ ). The origin of undershooting spikes may be threefold: immature properties of CR cells (Zhou and Hablitz, 1996), probably including low Na channel densities (Mienville et al., 1994); attenuation of dendritic spikes; and partial steady-state inactivation of $\mathrm{Na}$ channels because of the low RP. Because of their high density of clearly identifiable CR cells, we used P5 slices to test several hypotheses that may explain this low RP. Because GABA depolarizes CR cells (Fig. 2D,H) up to the time of their disappearance (Mienville, 1998b) and because these cells appear to be GABAergic (Pesold et al., 1998), one possibility was that ambient GABA released in Layer I by CR or other cells may induce a sustained depolarization. This hypothesis could be rejected because a concentration of bicuculline that completely abolishes GABAmediated currents in CR cells (Mienville, 1998b) failed to alter RP measured with perforated-patch techniques (Fig. 2E,H). Because no inward current can be induced by NMDA in the presence of $\mathrm{Mg}^{2+}$ in E18 CR cells (see Fig. 5A,C), an effect of ambient glutamate on NMDA receptors would not be expected at this age. However, this could be a mechanism for postnatal cells, because NMDA is depolarizing in the presence of $\mathrm{Mg}^{2+}$ (Fig. $2 F, H)$. Such a possibility nevertheless was ruled out because a concentration of CPP that antagonized most of NMDA current (see Fig. 4) was without effect on RP (Fig. 2G,H). The only extracellular manipulation that hyperpolarized CR cells was the substitution of bath $\mathrm{Na}^{+}$with $N$-methyl-D-glucamine (NMG; Fig. $2 A, H$ ). (This appeared to be a true effect because it was repeated with a $3 \mathrm{M} \mathrm{KCl}$ bridge to avoid contamination of the reference electrode; moreover, we measured a junction potential NMG$\mathrm{NaCl}$ of only $-2 \mathrm{mV}$.) Several mechanisms could account for this effect, including the presence in CR cells of (1) a persistent $\mathrm{Na}$ conductance $\left(I_{\mathrm{NaP}}\right)$, (2) a $\mathrm{Na} / \mathrm{Ca}$ exchange system, (3) a $\mathrm{Na}$ dependent uptake of amino acids, or (4) a deficiency of the $\mathrm{Na} / \mathrm{K}$ ATPase pump.

The first candidate was eliminated on the basis of the failure of tetrodotoxin (TTX) to alter RP (Fig. 2B,H) at a concentration, 1 $\mu \mathrm{M}$, that blocks $I_{\mathrm{NaP}}$ (Crill, 1996). (We cannot exclude, however, a TTX-insensitive $I_{\mathrm{NaP}}$.) The second option also was eliminated because adding $10 \mathrm{~mm}$ EGTA to the pipette solution to buffer $\left[\mathrm{Ca}^{2+}\right]_{\mathrm{i}}$ yielded a mean RP $(-53.4 \pm 2.1 \mathrm{mV} ; n=13)$ not significantly different $(p=0.18)$ from control $(-48.7 \pm 2.4 \mathrm{mV}$; $n=8)$. In fact, contrary to our expectation, mean RP measured after $10 \mathrm{~min}$ in the whole-cell configuration was more depolarized $(-43.8 \pm 2.9 \mathrm{mV}$; Fig. $2 H)$ than in control $(-52.1 \pm 3.1 \mathrm{mV} ; p=$ 0.08). This was attributable, in part, to three cells that failed to repolarize completely after a burst of spikes (e.g., Fig. $2 C$ ) or even a single spike, which may point to a functional role of largeconductance Ca-activated $\mathrm{K}$ channels in CR cells (Mienville, 1998b) for RP maintenance. The third possible mechanism, a symport of $\mathrm{Na}^{+}$with amino acids, was attractive because CR cells synthesize an unusually large protein, Reelin (D'Arcangelo et al., 1995), and our bath medium contains amino acids (see Materials and Methods). Unfortunately, omitting these amino acids from the bath did not change mean RP $(-51.8 \pm 1.3 \mathrm{mV} ; n=12)$. Finally, the possibility remained of a defective $\mathrm{Na} / \mathrm{K}$ ATPase activity. After $10 \mathrm{~min}$ of whole-cell dialysis with a pipette solution containing $4 \mathrm{~mm}$ ATP, RP reached a value that was hyperpolarized, in large part, as compared with that measured on break-in $\left(-48 \pm 1.6 \mathrm{mV} ; p=3 \times 10^{-6}\right.$; two-tailed paired $t$ test; Fig. $\left.2 H\right)$ and with those measured in the initial age groups in the absence of ATP $\left[10^{-6}>p>10^{-10}\right.$; ANOVA plus Least Significant Difference (LSD) post hoc; see Fig. 1], but not different from that of Layer II cells ( $p=0.6$; see Fig. 1$)$. This observation parallels the idea that a defective $\mathrm{Cl}^{-}$pump might be responsible for the persistent depolarizing action of GABA (Mienville, 1998b).

\section{Postnatal increase in the functional expression of NMDA receptors}

Figure 3 summarizes dose-response data for inward currents activated by NMDA in CR cells at various developmental stages. The most conspicuous change concerns the eightfold increase in maximum current density from E18 to P11, which we interpret as an increase in receptor number (see below). Because there was no significant difference in maximum current density between P5 and P13 ( $p=0.2$, ANOVA; Fig. 3D, Table 1$)$, we conclude that the functional expression of NMDA receptors in CR cells plateaus perinatally. In contrast, neither the $\mathrm{EC}_{50}$ of $\mathrm{NMDA}$ nor the Hill number changed (Fig. 3D, Table 1). Note that the rate of current desensitization increased with agonist concentration despite the presence of $10 \mu \mathrm{M}$ glycine (McBain and Mayer, 1994); 

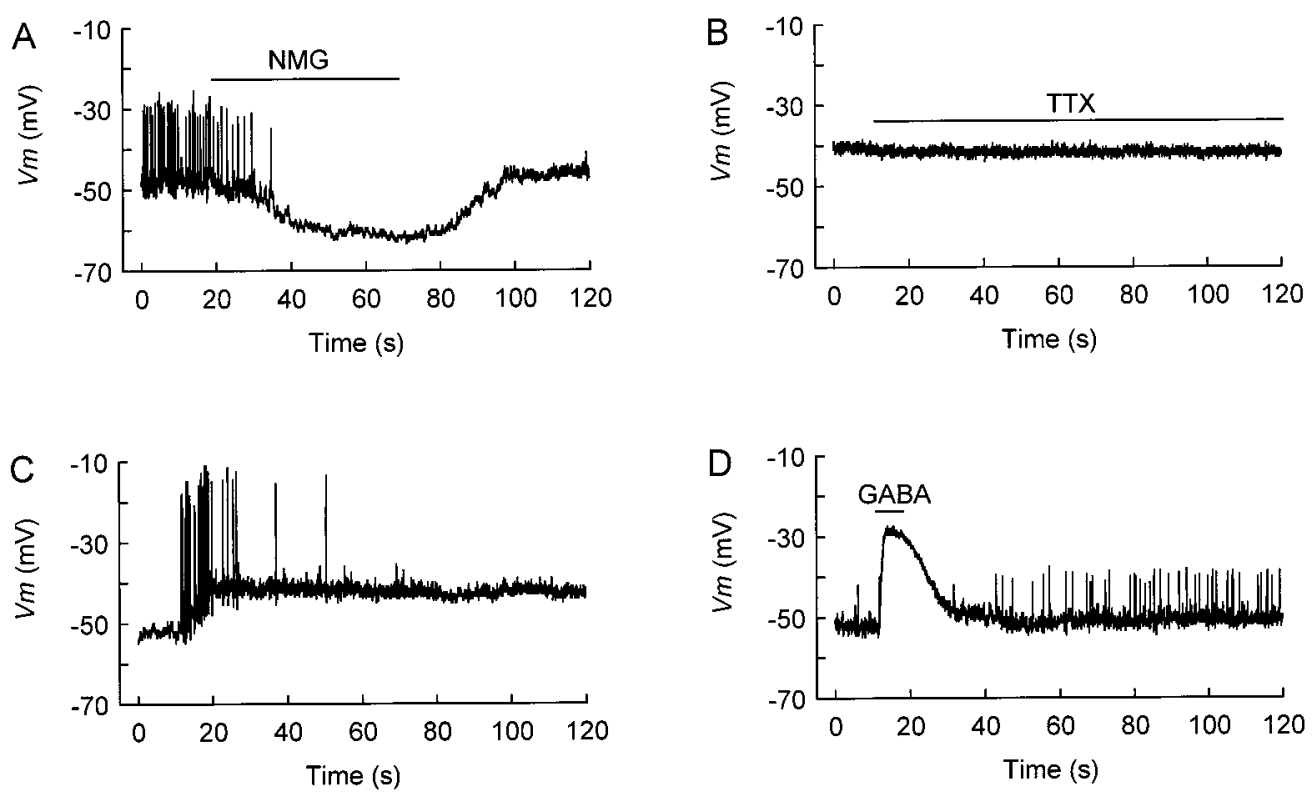

Figure 2. Modulation of $\mathrm{CR}$ cell resting potential by various agents. $A$, Local substitution of extracellular $\mathrm{Na}^{+}$ions by $N$-methyl-D-glucamine $(N M G)$ hyperpolarizes membrane potential $\left(V_{\mathrm{m}}\right)$ and blocks spontaneous firing. For unknown reasons, firing was not restored immediately on

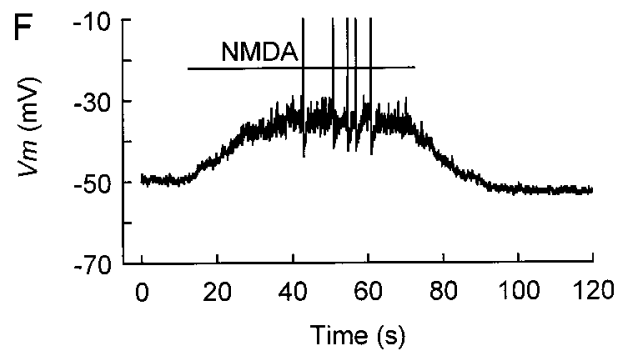
return to control $\left(\mathrm{Na}^{+}\right.$-rich) medium

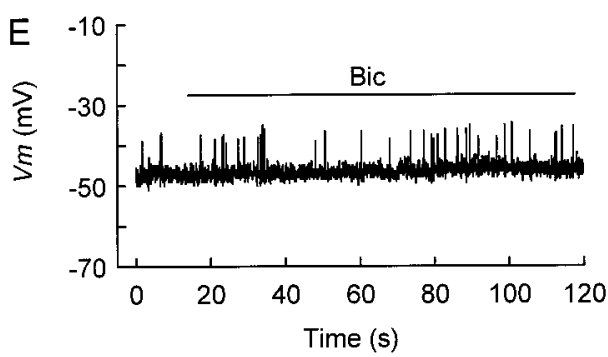
but reappeared 3.8 min later. $B$, Tetrodotoxin $(T T X ; 1 \mu \mathrm{M})$ fails to change $V_{\mathrm{m}}$. $C$, After $7 \mathrm{~min}$ of wholecell recording with $10 \mathrm{~mm}$ EGTA in the pipette, a burst of action potentials steadily depolarizes $V_{\mathrm{m}} . \quad D$, GABA $(100 \mu \mathrm{M})$ transiently depolarizes $V_{\mathrm{m}}$, producing a shunting inhibition of firing. $E$, Bicuculline fails to affect $V_{\mathrm{m}}$ or firing. $F$, NMDA (100 $\mu \mathrm{M})$ depolarizes $V_{\mathrm{m}}$ to spike threshold (the spikes are truncated). $G$, CPP does not affect $V_{\mathrm{m}}$. $H$, Summary of the effects of the drugs that were tested. Zero is taken as the initial resting potential; a negative value indicates hyperpolarization, and a positive value corresponds to depolarization. The numbers above the error bars indicate the number of cells tested. $A, D, E$, Perforated-patch recording. $B, C, F, G$, Whole-cell recording. All tests were performed in regular Ringer's (plus $2 \mathrm{mM} \mathrm{Mg}^{2+}$; no glycine was added). Drugs were applied for the duration indicated by bars above the traces.

perhaps relevant to that observation is the fact that "postdesensitization humps" (i.e., a rebound current on agonist removal) were occasionally present at the highest agonist concentration, both in embryonic and postnatal cells (Fig. $3 A, B$ ). This phenomenon, which might be attributable to agonist blockade of the channel (Colquhoun and Ogden, 1988), does not occur with $\mathrm{GABA}_{\mathrm{A}}$ receptors activated in the same experimental conditions (Mienville, 1998b) but has been observed with NMDA receptors activated in cultured neurons (Westbrook et al., 1986).

Preliminary pharmacology of NMDA receptors expressed on embryonic and postnatal CR cells was investigated with two specific antagonists, CPP and D-2-amino-5-phosphonopentanoic acid (D-AP-5). One of our concerns here was the fact that Del Río et al. (1996) reported that in neocortical organotypic cultures D-AP-5 was unable to prevent CR cell death; we therefore wanted to check whether NMDA receptors in CR cells are sensitive to classical antagonists. In our hands, equipotent concentrations of CPP and D-AP-5 blocked most of the NMDA current in both embryonic and postnatal CR cells (Fig. 4A,B, Table 1).

\section{Current-voltage (I/V) relationships of NMDA currents in prenatal and postnatal CR cells}

The voltage dependence of NMDA currents was studied in E18 and P12 CR cells bathed in nominally $\mathrm{Mg}^{2+}$-free medium versus "physiological" medium containing $2 \mathrm{mM} \mathrm{Mg}^{2+}$, both supplemented with $10 \mu \mathrm{M}$ glycine. At E18, no inward current could be evoked in the presence of $\mathrm{Mg}^{2+}$ (Fig. 5A,C). At P12, the $I / V$ relationship in the presence of $\mathrm{Mg}^{2+}$ had the usual region of negative conductance and indicated that a $V_{\mathrm{m}} \leq-60 \mathrm{mV}$ essentially would prevent ion flow through NMDA channels (Fig. 

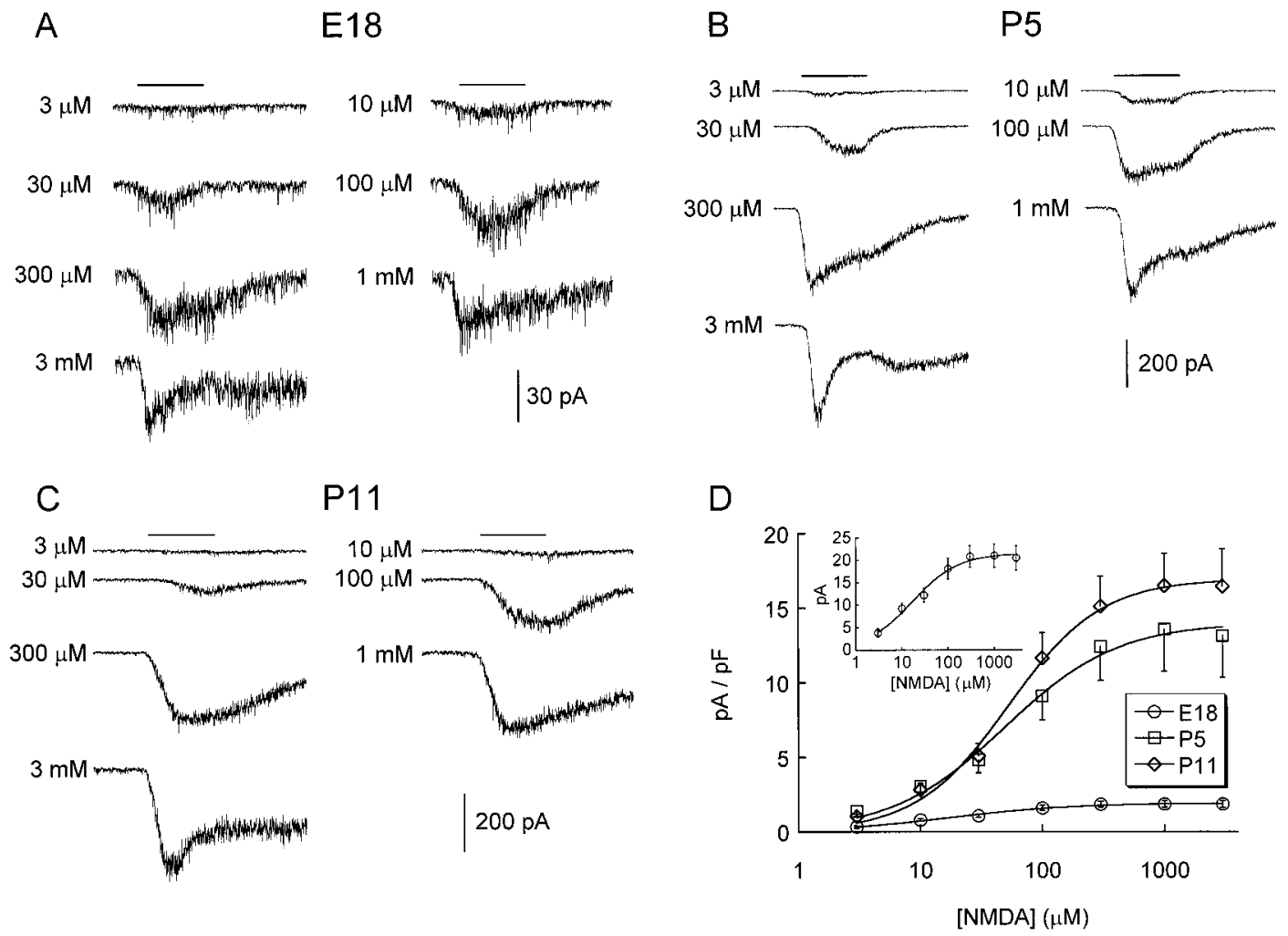

Figure 3. Dose-response properties of NMDA-activated currents in embryonic and postnatal CR cells. $A-C$, Representative traces obtained at different ages with various concentrations of NMDA applied for $3 \mathrm{sec}$, as indicated by the bars above the traces. $D$, Corresponding concentration-current density (I) data fit with an equation of the form: $I=I_{\max }[\mathrm{NMDA}]^{n H} /\left(\mathrm{EC}_{50}{ }^{n H}+[\mathrm{NMDA}]^{n H}\right)$, where $n H=$ Hill number. Parameter values are reported in Table 1. The inset shows non-normalized data for E18 CR cells. Currents were recorded with CsCl pipettes at a holding potential of $-60 \mathrm{mV}$. The extracellular medium was nominally $\mathrm{Mg}^{2+}$-free and contained $10 \mu \mathrm{M}$ glycine.

Table 1. NMDA receptor channel properties in Cajal-Retzius cells at E18, P5, and P11-P13

\begin{tabular}{|c|c|c|c|c|c|c|c|}
\hline & $I_{\max }(\mathrm{pA} / \mathrm{pF})$ & $\mathrm{EC}_{50}(\mu \mathrm{M})$ & $n_{\text {Hill }}$ & $\begin{array}{l}\text { CPP antag } \\
(\%)\end{array}$ & $\begin{array}{l}\text { AP-5 antag } \\
(\%)\end{array}$ & $\gamma(\mathrm{pS})$ & $\tau(\mathrm{msec})$ \\
\hline E18 & $2.2 \pm 0.3^{*}$ & $47.6 \pm 14.2$ & $1.2 \pm 0.2(17)$ & $78 \pm 2.9(6)$ & $75.1 \pm 5.5(6)$ & $37.3 \pm 1.5$ & $2.8 \pm 0.2(11)$ \\
\hline P5 & $14.2 \pm 2.6$ & $53.7 \pm 8.5$ & $1.0 \pm 0.1(12)$ & ND & $\mathrm{ND}$ & $37.3 \pm 2.2$ & $2.9 \pm 0.2(14)$ \\
\hline P11-P13 & $17.7 \pm 2.4$ & $57.7 \pm 7.8$ & $1.1 \pm 0.1(16)$ & $84.2 \pm 4.0(3)$ & $84.2 \pm 0.8(3)$ & $40.3 \pm 1.6$ & $2.9 \pm 0.1(16)$ \\
\hline Layer II & $\mathrm{ND}^{a}$ & ND & ND & ND & ND & $36.4 \pm 4.3$ & $2.5 \pm 0.1(4)$ \\
\hline
\end{tabular}

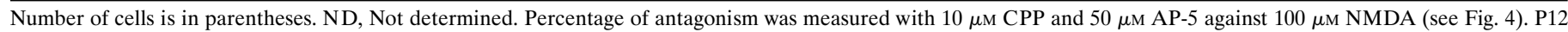
Layer II neurons are included for comparisons of single-channel conductance $(\gamma)$ and gating time constant $(\tau)$.

*Significantly different ( $p=10^{-6}$, ANOVA).

${ }^{a}$ At $100 \mu \mathrm{M}$ NMDA, current density is already larger than $I_{\max }$ in CR cells, with $22.3 \pm 4.1 \mathrm{pA} / \mathrm{pF}(n=5)$.

$5 B, D)$. We do not think that the lack of inward current at E18 implies a difference in $\mathrm{Mg}^{2+}$ sensitivity of embryonic versus postnatal cells. Rather, the small amplitude of embryonic currents (see Fig. 3D, inset) simply may not allow their detection at negative $V_{\mathrm{m}}$ in the presence of the divalent. In the virtual absence of $\mathrm{Mg}^{2+}$, embryonic and postnatal $I / V$ relationships displayed similar outward rectification (Fig. $5 C, D$ ), possibly because of contaminating $\mathrm{Mg}^{2+}$ in the medium.

\section{Lack of change in NMDA receptor function in prenatal and postnatal CR cells}

Developmental changes in the expression of NMDA receptor subunits have been reported for various brain regions (Monyer et al., 1994), including cortex (Sheng et al., 1994). Given the fact that specific subunit assemblies confer different biophysical properties to both recombinant (McBain and Mayer, 1994; Monyer et al.,
1994) and native NMDA channels (Momiyama et al., 1996), we investigated whether NMDA channels expressed in CR cells might display developmental changes in their properties. Figure 6 illustrates representative traces and plots used for noise analysis of NMDA currents recorded in E18 (Fig. 6, left panels) and P12 cells (Fig. 6, right panels). Single-channel conductance $(\gamma)$ was not different in early versus late CR cells (Table 1) and was similar to that obtained in cultured hippocampal neurons (Mayer et al., 1988) and neocortical neurons recorded in situ (LoTurco et al., 1991). Power spectra of steady-state currents evoked by NMDA at both ages in most cases ( $>80 \%$ of spectra) could be fit with a single Lorentzian. The time constant $(\tau)$ obtained from such fits did not change during CR cell development. Moreover, both $\gamma$ and $\tau$ were similar to values obtained in a few experiments with well developed Layer II pyramidal neurons (Table 1). Values for 

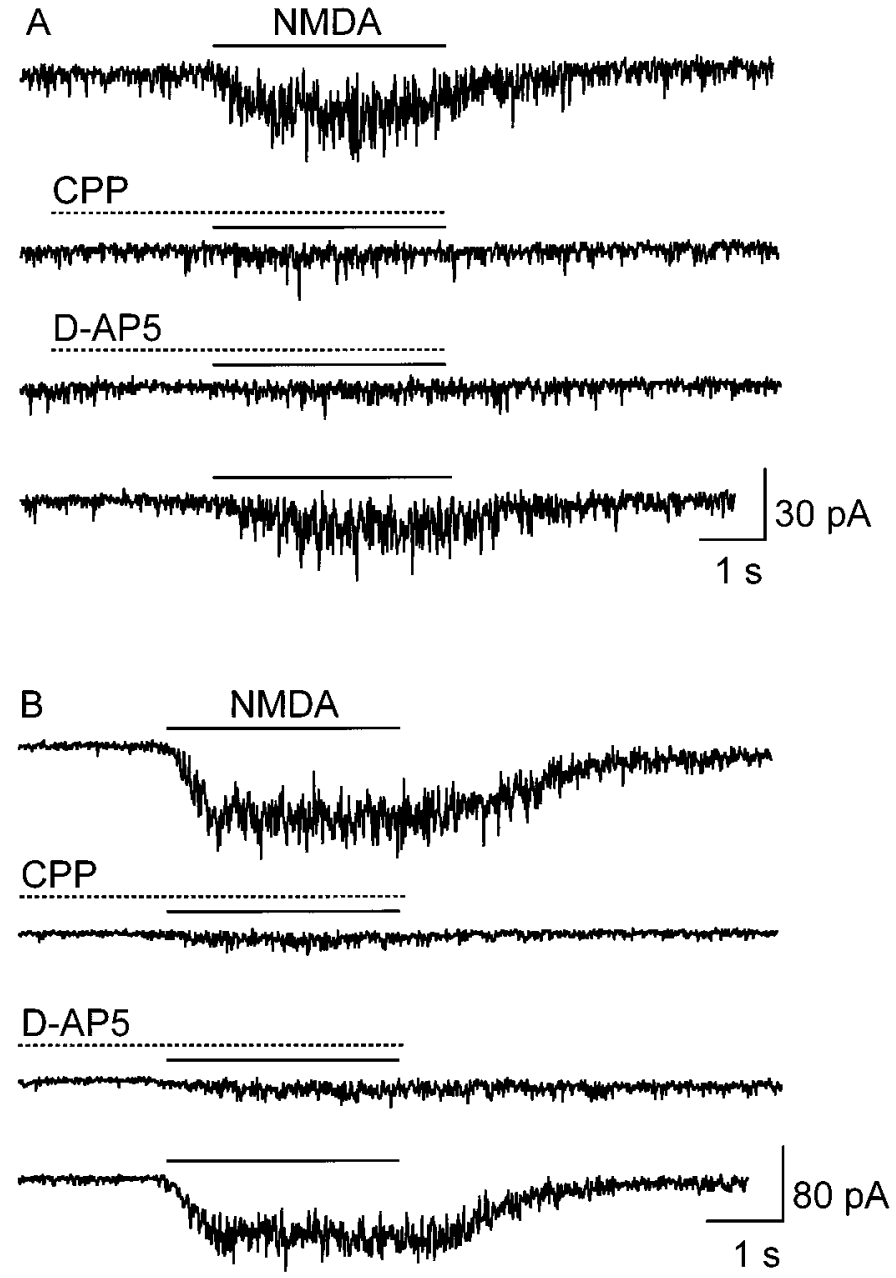

Figure 4. Antagonism of NMDA-activated currents by CPP $(10 \mu \mathrm{M})$ and D-AP-5 $(50 \mu \mathrm{M}) . A$, E18 CR cell. $B$, P12 CR cell. Antagonists were preapplied for $2 \mathrm{sec}$ and coapplied with $100 \mu \mathrm{M}$ NMDA for $3 \mathrm{sec}$, as indicated by the bars. The bottom traces in each panel show recovery from antagonist blockade. Conditions: $\mathrm{CsCl}$ pipettes; holding potential, -60 $\mathrm{mV} ; \mathrm{Mg}^{2+}$-free, $10 \mu \mathrm{M}$ glycine-supplemented bath.

$\tau$ were somewhat faster than the 5-6 msec values usually obtained with a $1 \mathrm{kHz}$ bandwidth from noise analysis (Mayer et al., 1988) or single-channel experiments (LoTurco et al., 1991). Consistent with these differences, increasing bandwidth can induce a second, faster $(\sim 1 \mathrm{msec})$ component in the mean open time of NMDA channels (Jahr and Stevens, 1987; Blanton et al., 1990). Because shorter mean open times can be induced by $\mathrm{Mg}^{2+}$ concentrations as low as $10 \mu \mathrm{M}$ (Nowak et al., 1984), our faster kinetics might be attributable to the presence of contaminating $\mathrm{Mg}^{2+}$ [see also Momiyama et al. (1996), who found a single mean open time of $3.5 \mathrm{msec}$ for the $50 \mathrm{pS}$ channel in nominally $\mathrm{Mg}^{2+}$-free solution]. Our observation that NMDA receptors have similar biophysical properties in embryonic and postnatal CR cells parallels the results of LoTurco et al. (1991) on prenatal and postnatal cortical plate neurons.

These results, however, do not rule out the possibility that different NMDA receptor subunits with similar biophysical properties are expressed during the development of CR cells. Such might be the case, for example, of the NR2A and NR2B subunits, which share common conductance and kinetic properties (Stern et al., 1992) and have been shown to be expressed at different stages of development, NR2A exclusively appearing postnatally (Monyer et al., 1994; Sheng et al., 1994). We have investigated this issue with the drug ifenprodil, which preferentially blocks current through NMDA channels containing NR2B subunits (Williams, 1993). The same degree of antagonism elicited in prenatal and postnatal $\mathrm{CR}$ cells (Fig. $7 A, B, D$ ) strongly suggests that no change in the NR2A/NR2B ratio occurs in these cells. The fact that $100 \mu \mathrm{M}$ ifenprodil almost abolished NMDA responses also suggests a high proportion of NR2B subunits (Williams, 1993). By contrast, NMDA currents recorded in $\sim 2$-week-old Layer II pyramidal cells were much less sensitive to ifenprodil (Fig. 7C,D), indicating that in these cells the switch to NR2A expression likely had occurred (Monyer et al., 1994; Sheng et al., 1994).

\section{In vivo prevention of CR cell death with dizocilpine}

To test directly the involvement of NMDA receptors in CR cell death, we have performed pilot experiments, using in vivo treatment with dizocilpine, a specific noncompetitive antagonist of NMDA receptors. Rat pups treated with $0.5 \mathrm{mg} / \mathrm{kg}$ dizocilpine were severely underweight (44\% of control), essentially caused by malnutrition as previously reported (Gorter et al., 1991; Gould et al., 1994); other developmental parameters such as hair growth did not seem to be affected. In these animals the number of live CR cells was more than threefold that observed in control (30 \pm 2 vs $9 \pm 1 ; n=3$ each). A similar ratio was observed with G10-stained cells ( $45 \pm 6$ in treated animals vs $13 \pm 1$ in control animals; Fig. $8 A, B$ ). The larger number of cells counted with G10 staining is probably attributable to the fact that it permitted detection of cells deeper in the slice than morphological identification would allow. Because of the smaller brain sizes in the treated group, the difference between treated and control animals was amplified when normalizing to tissue volume $(94 \pm 12$ cells/ $\mathrm{mm}^{3}$ in treated animals vs $25 \pm 3$ cells $/ \mathrm{mm}^{3}$ in controls).

Rats treated with $0.1 \mathrm{mg} / \mathrm{kg}$ dizocilpine maintained a weight from $83 \%$ (lowest) of control on day 5 (P10) to $\sim 89 \%$ of control on the last day of treatment. Their eyes opened on the same day (P18) as controls. In these conditions the number of G10-labeled CR cells was similar in hemislices from control $(9 \pm 1$ cells; $15 \pm$ 2 cells $\left./ \mathrm{mm}^{3}\right)$ and treated animals $\left(10 \pm 1\right.$ cells; $16 \pm 2$ cells $/ \mathrm{mm}^{3}$; Fig. $8 C, D$ ). Our initial goal with this protocol, which used a milder but longer treatment, was to obviate unspecific effects and at the same time determine whether any CR cells would survive well beyond the expected period of disappearance. The fact that some Reelin-positive CR cells can be found in control animals at this age is consistent with a "background" population of CR cells persisting into adulthood (Marín-Padilla, 1998). This finding argues against a possible interpretation of our results, namely that CR cells, instead of dying, would stop expressing Reelin and that dizocilpine somehow would restore expression. Another worthwhile observation at P20 is the fact that cells, including some in Layer I, with morphological features different from those of CR cells are Reelin-immunopositive (Fig. 8C,D; Pesold et al., 1998). These cells are unlikely to be metamorphosed CR cells because (1) they can be observed at a time (P6) when many CR cells are still present (Schiffmann et al., 1997), (2) they have been found to belong to specific categories such as bitufted/double bouquet neurons, and (3) they are essentially immunonegative to calretinin, another CR cell marker (C. Pesold et al., 1999). 
A

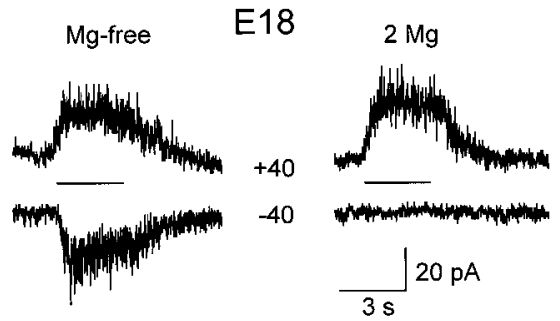

Figure 5. Magnesium dependence of current-voltage relationships for NMDA responses in prenatal and postnatal CR cells. $A$, $B$, Representative traces obtained with $\mathrm{CsCl}$ pipettes at symmetrical voltages $( \pm 40 \mathrm{mV})$, as indicated. NMDA $(100 \mu \mathrm{M})$ was applied for $3 \mathrm{sec}$, as shown by the bars between the traces. Glycine $(10 \mu \mathrm{M})$ was present in both $\mathrm{Mg}^{2+}$-free and $2 \mathrm{mM} \mathrm{Mg}^{2+}$ conditions. $C, D$, Current amplitude was normalized to values obtained at $+60 \mathrm{mV}$ and is plotted against the holding potential $(V)$.

Figure 6. Noise analysis of NMDAactivated currents in prenatal and postnatal CR cells. Left panels, E18 data; right panels, $\mathrm{P} 12$ data. Top panels show representative traces low-passfiltered at $10 \mathrm{kHz}$ (top) and high-passfiltered at $5 \mathrm{~Hz}$ (bottom). NMDA (100 $\mu \mathrm{M})$ was applied at the time indicated by the leftmost arrow. Onset periods between arrows were included in variance analysis plots and excluded from spectral analysis plots. Middle panels show corresponding variance versus mean current plots fit with a linear (left) or parabolic (right) curve, yielding single-channel conductances of, respectively, 39.9 and $36.1 \mathrm{pS}$. Bottom panels show corresponding power spectra fit with a Lorentzian function yielding a cutoff frequency (arrow) of $60.9 \mathrm{~Hz}$ (left) and $54.1 \mathrm{~Hz}$ (right), resulting in a channel-gating time constant of 2.6 and $2.9 \mathrm{msec}$, respectively. Conditions: $\mathrm{CsCl}$ pipettes; holding potential, $-60 \mathrm{mV} ; \mathrm{Mg}^{2+}$-free, $10 \mu \mathrm{M}$ glycine-supplemented bath.

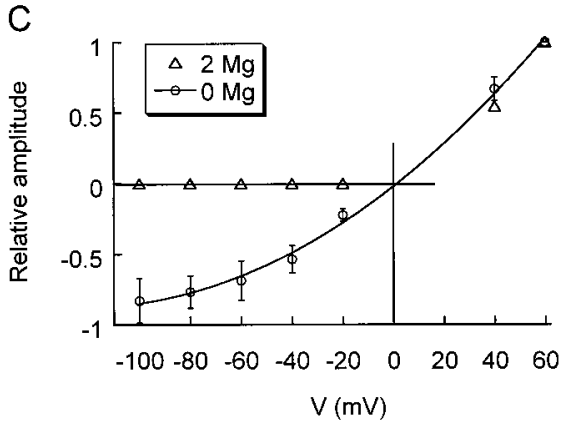

E18
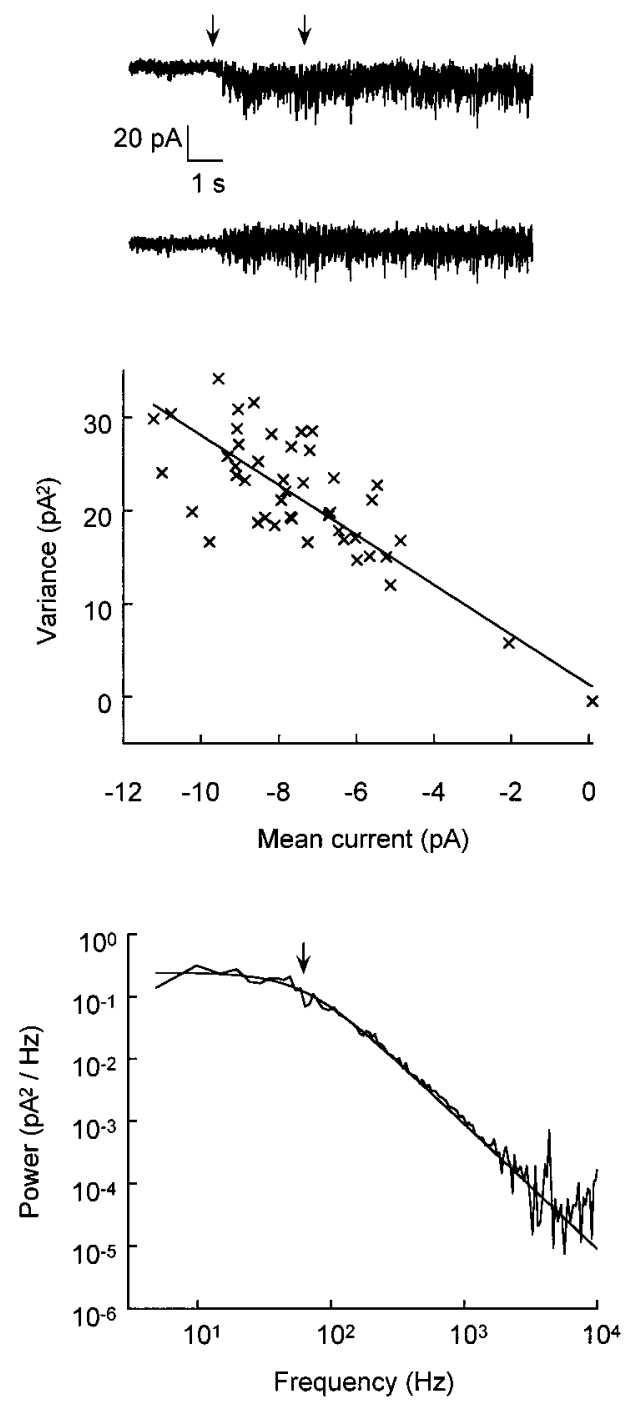
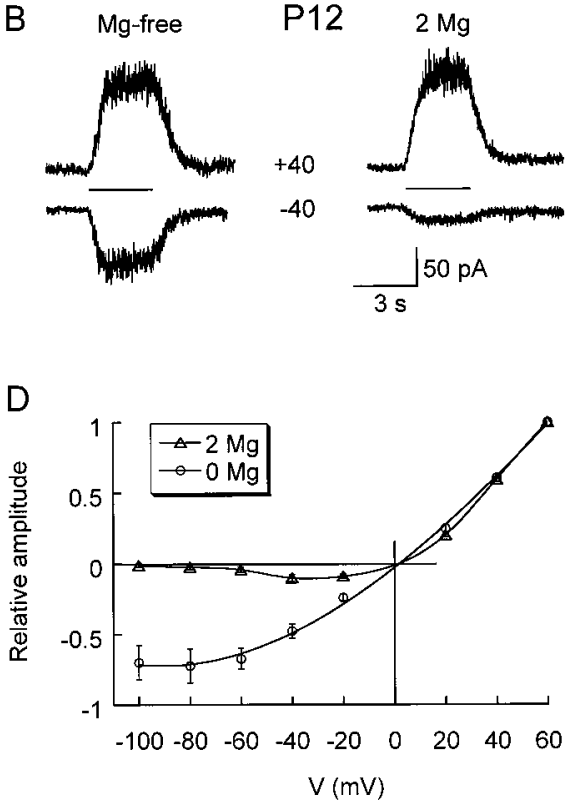

P12
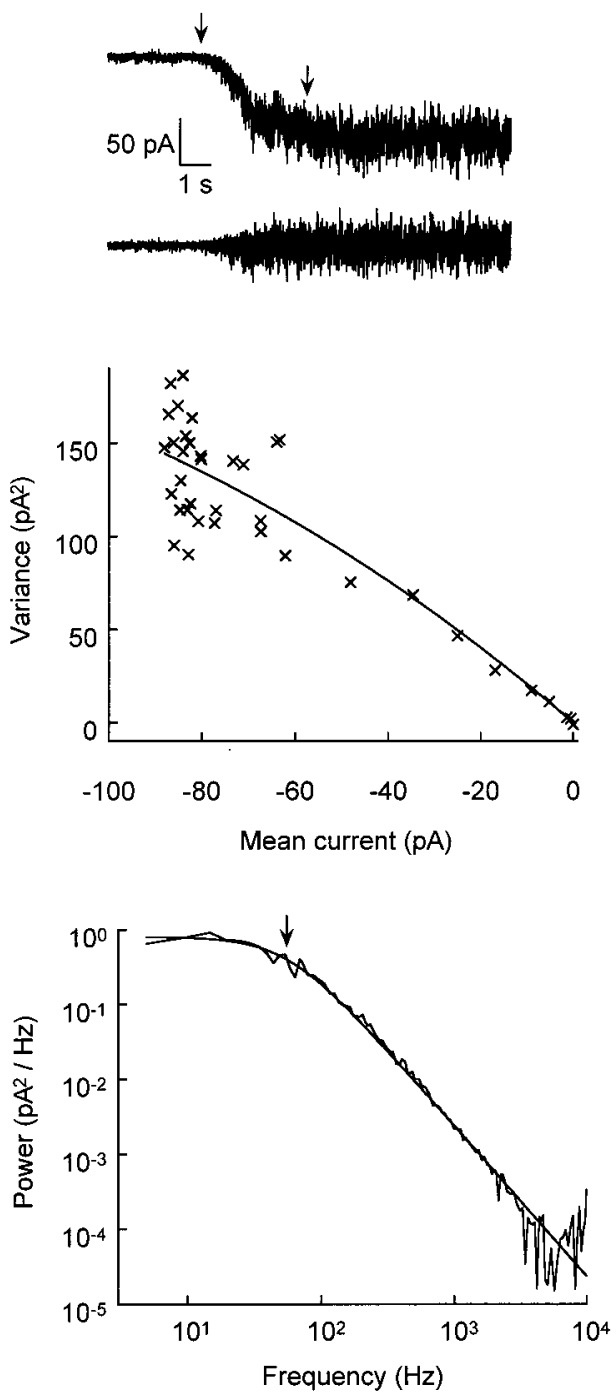

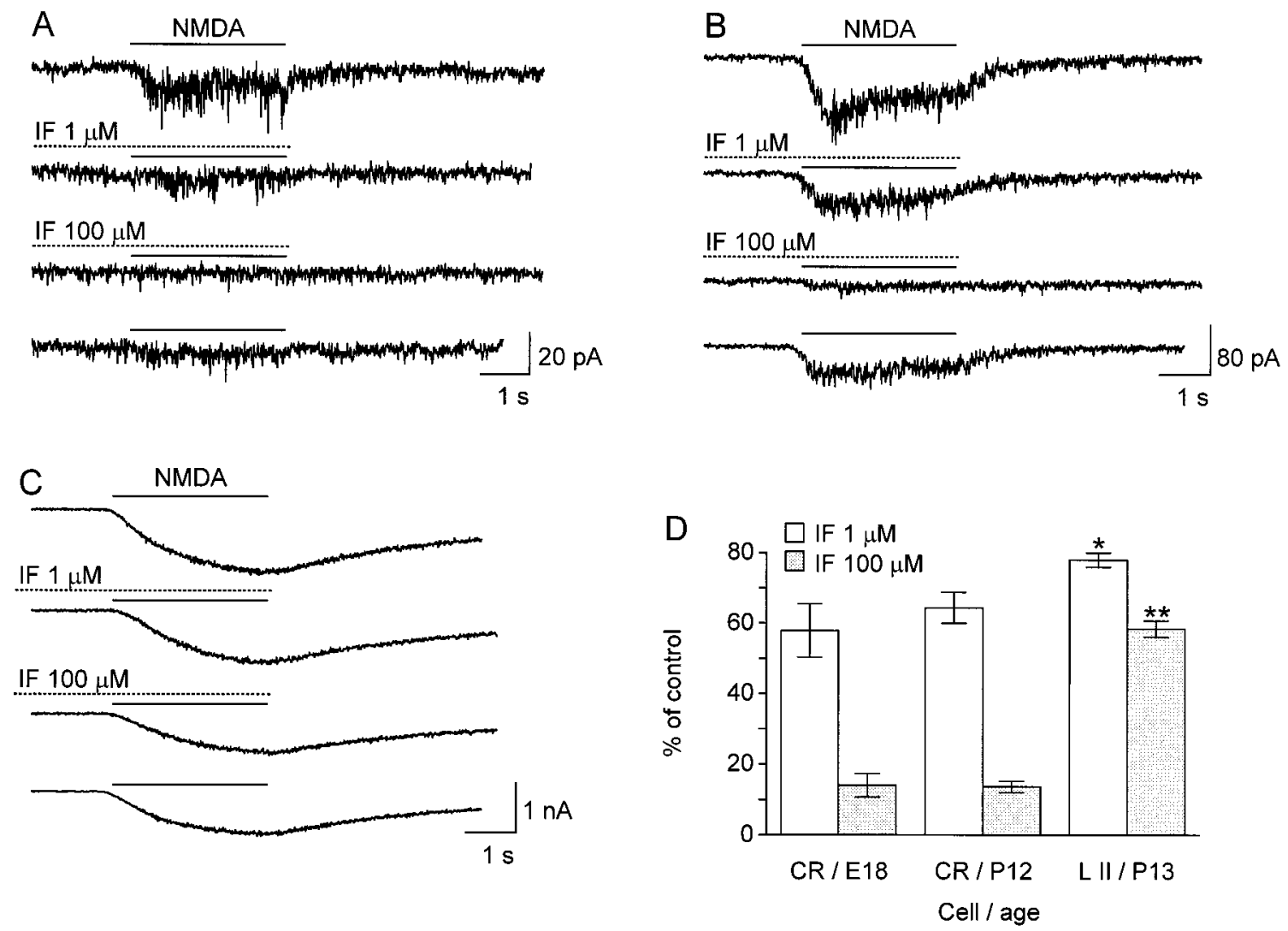

Figure 7. Antagonism of NMDA currents by ifenprodil $(I F)$ in prenatal and postnatal CR cells and in Layer II pyramidal neurons. $A$, E18 CR cell. $B$, P12 CR cell. $C$, P13 Layer II pyramid. This is the same type of experiment as in Figure 4, except that $I F$ was preapplied manually for 15-20 sec before the automatic $2 \mathrm{sec}$ preexposure. Recovery took longer (5-10 min to maximum) than with competitive antagonists (Fig. 4 shows immediate recovery) and consequently might be confounded by time-dependent rundown. The slower kinetics in $C$ is probably attributable to extensive arborization of the pyramidal cells and asynchronous activation of remote receptors. $D$, Summary of NMDA current remaining (expressed as a percentage of control) after the application of 1 or $100 \mu \mathrm{M}$ ifenprodil to E18 $(n=11)$ and P12 $(n=8)$ CR cells and P13 Layer II neurons $(n=15)$. Comparisons within each concentration group yield ${ }^{*} p=0.006$ and ${ }^{* *} p=3 \times 10^{-12}$ (ANOVA). No difference was found between prenatal and postnatal CR cells $(p=0.32$ and 0.92 for 1 and $100 \mu \mathrm{M}$, respectively; LSD).

\section{DISCUSSION}

\section{Resting potential of $C R$ cells}

A number of reports (Ramoa and McCormick, 1994; Kim et al., 1995) have documented the low RP of developing cells, which later become more hyperpolarized as neuronal circuits mature. Cajal-Retzius cells, which are present mainly in immature tissue, also fall into this category of relatively depolarized cells. In our hands, however, this feature appears to persist up to the time of their disappearance. Zhou and Hablitz (1996) also found a low RP for perinatal CR cells, but they noted a trend toward hyperpolarization during the second postnatal week. Although this discrepancy might be related to a difference in sampling size (23 CR cells in their case vs 114 in ours), their including ATP in the intracellular solution could be relevant also. Indeed, we find that including $4 \mathrm{~mm}$ ATP together with a regenerating system (phosphocreatine) polarizes CR cells to a "normal" RP similar to that of Layer II pyramidal neurons. It is further interesting to note that Hestrin and Armstrong (1996), who used 4 mм ATP, measured a CR cell RP of $-64 \mathrm{mV}$, whereas Zhou and Hablitz (1996) used 2 mM ATP. That such a concentration difference would be relevant seems like a challenging concept; however, one must be reminded that electrically active cells-which is the case of CR cells-may use up to two-thirds of their energy requirement to fuel the $\mathrm{Na} / \mathrm{K}$ pump (Alberts et al., 1994). Protein synthesis is another taxing work requiring four high-energy phosphate bonds per peptidic bond linkage (Alberts et al., 1994). Because the role of CR cells in neuronal migration depends on their synthesis of Reelin, a very large protein $>3000$ amino acid residues long (D'Arcangelo et al., 1995), this synthesis could use endogenous ATP, and this might be achieved at the expense of a low RP. Inconsistent with this view, however, is the fact that cultured cerebellar granule cells also synthesize and release substantial amounts of Reelin (A. Guidotti, personal communication) although their RP is fairly high (approximately $-70 \mathrm{mV}$, personal observation). Therefore, another possibility that might be considered is a difference in the $\mathrm{Na} / \mathrm{K}$ pump isozymes that operate in these cells, perhaps with various efficacies and substrate affinities (Sweadner, 1989).

\section{Functional expression of NMDA receptors in CR cells}

A dramatic increase in NMDA-activated current occurred in postnatal CR cells. Because neither single-channel conductance nor kinetics showed any change during the postnatal transition, we can assert that this increase in current amplitude is entirely attributable to an increase in receptor density. Moreover, none of the specific parameters of receptor function $\left(\mathrm{EC}_{50}\right.$, Hill number, sensitivity to antagonists) changed, suggesting that the same receptor species is expressed throughout the life of CR cells. 


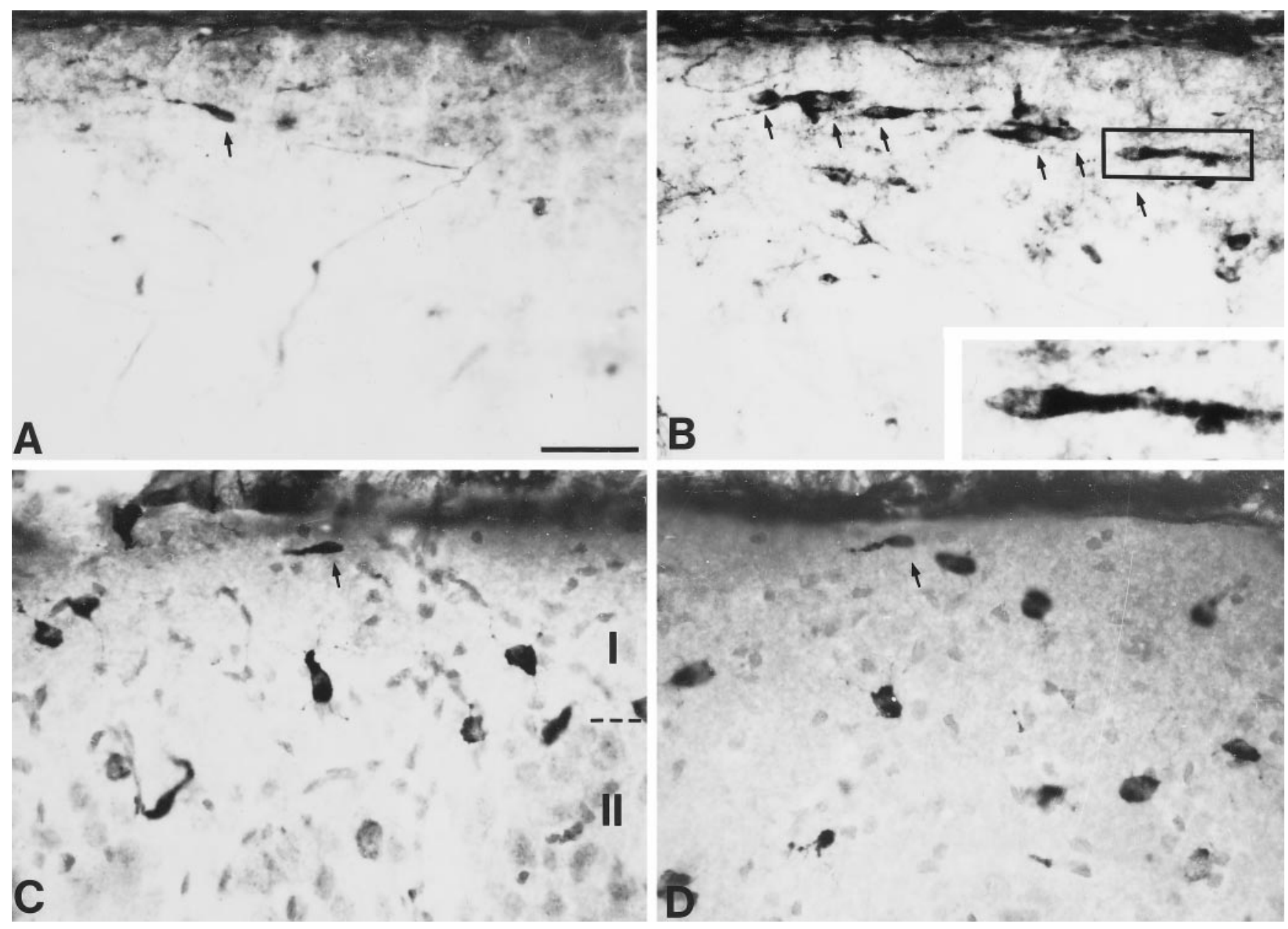

Figure 8. Effects of dizocilpine treatment on neocortical CR cell number. $A, B$, Photomicrographs show $\mathrm{CR}$ cells in the marginal zone of $\mathrm{P} 13$ rats treated with vehicle $(A)$ or $0.5 \mathrm{mg} / \mathrm{kg}$ dizocilpine $(B)$. Inset in $B$ is a higher magnification of the CR cell in the box. Note the presence of extracellular Reelin in the marginal zone as well as the greater number of CR cells (indicated by arrows) in the dizocilpine-treated animal. $C$, $D$, Layers I and II of the intermediate cortex of P20 rats treated with vehicle $(C)$ or $0.1 \mathrm{mg} / \mathrm{kg}$ dizocilpine $(D)$. Darkly stained cells are Reelin-positive, and lightly stained cells are labeled with a neutral red counterstain. Note that, besides the presence of a few remaining CR cells (arrows), the majority of Reelin-positive cells in Layer I do not have the typical CR cell morphology (lack of blood vessel staining artifact in P20 rats is attributable to perfusion). Scale bar, $40 \mu \mathrm{m}$ $(16 \mu \mathrm{m}$ for inset).

Schwartz et al. (1998) have shown that, of Layer I cells from P1-P8 rats, CR cells are the most responsive to NMDA application, with $100 \%$ of large CR cells responding to agonist with an increase in $\left[\mathrm{Ca}^{2+}\right]_{\mathrm{i}}$. However, these ratiometric measurements were not calibrated; in the context of our hypothesis it would be interesting to see if absolute $\left[\mathrm{Ca}^{2+}\right]_{\mathrm{i}}$ values in $\mathrm{CR}$ cells are widely different from those found in other cells, which may allow for the assessment of toxic $\mathrm{Ca}^{2+}$ levels.

\section{A possible scenario for physiological cell death}

The idea of a lethal combination between low RP and NMDA receptor activation has been suggested previously in the context of pathological cell death (Novelli et al., 1988). In this study various manipulations aimed at decreasing energy levels in cultured cerebellar granule cells led to $\mathrm{Na} / \mathrm{K}$ pump failure (presumably followed by depolarization and the release of NMDA channels from $\mathrm{Mg}^{2+}$ block) and subsequent vulnerability to glutamate or NMDA application. Should glutamate-or any NMDA agonist-be physiologically present in brain extracellular space, the same scenario may apply to any depolarized cells that express a sufficient density of NMDA receptors. Beyond evidence that glutamate and aspartate are present in brain extracellular fluids
(Johnson, 1978; Lerma et al., 1986), the most convincing demonstration comes from studies that showed tonic, endogenous activation of NMDA channels (Sah et al., 1989; Blanton et al., 1990; LoTurco et al., 1991). In the present work we did not see any effect of CPP on CR cell RP, which argues against the presence of an endogenous agonist in our slice preparation. This difficulty might be attributable to our using relatively thin slices and recording cells near their surface, whereas the authors mentioned above used thick slices and recording techniques (sharp electrodes or "blind" approach) that may target cells deeper in the slice. In fact, the presence of water-soluble molecules such as glutamate or GABA near the slice surface is highly unlikely (see also the lack of effect of bicuculline in Fig. $2 E$ ); only deep in the slice, perhaps in the vicinity of tonically releasing cells, can the presence of endogenous transmitters be anticipated. These considerations suggest that if CR cells are exposed in vivo to endogenous amino acids, their RP might even be lower than measured here.

Thus far, we are implying that such endogenous activities involving ambient amino acids would be of a tonic nature, which parallels the fact that CR cells do not appear to display sponta- 
neous postsynaptic currents (Mienville, 1998b). The lack of spontaneous synaptic activity is consistent with the paucity of synapses found on CR cells (Derer and Derer, 1990, 1992) and with the requirement for cortical plate or layer I stimulation to evoke postsynaptic currents in these cells (Kim et al., 1995; A. Kriegstein, personal communication). Therefore, it is likely that the NMDA receptors studied here were mainly extrajunctional. In synaptically connected networks, phasic NMDA receptor activation occurs subsequent to the initial depolarization provided by glutamate-activated, voltage-independent AMPA receptors (McBain and Mayer, 1994). In contrast with the robust responses to kainate - an agonist of AMPA receptors_-displayed by Layer II/III pyramidal neurons, CR cells generally did not respond to this drug at any developmental stage (J.-M. Mienville, unpublished data), consistent with the low percentage of CR cells found to respond to AMPA (Schwartz et al., 1998).

To summarize, then, our proposal, we postulate that CR cells maintain a low RP throughout their lives, probably because of a failure to meet all energy requirements. During embryogenesis the low density of NMDA receptors does not permit glutamateactivated, potentially toxic $\mathrm{Ca}^{2+}$ influx. Starting during early postnatal stages, CR cells express a large number of NMDA receptors that may be activated tonically by ambient glutamate perhaps released by newly arrived pyramidal neurons. Cells capable of maintaining a $\mathrm{RP} \geq 60 \mathrm{mV}$ are protected from NMDA receptor activation via $\mathrm{Mg}^{2+}$ blockade, whereas CR cells are not. The fact that $\mathrm{Ca}^{2+}$ extrusion requires energy would even worsen this situation, which is consistent with the fact that CR cells in rodents start degenerating during the first postnatal week (Derer and Derer, 1990, 1992). Healthier or more polarized CR cells may sustain the insult longer, but after the second postnatal week the $\left[\mathrm{Ca}^{2+}\right]_{\mathrm{i}}$ load would lead to irreversible damage and to their disappearance.

The most serious conflict with our hypothesis concerns the work of Del Río et al. (1996), who found that D-AP-5 was unable to protect CR cells in an in vitro system. Several factors might explain this lack of effect. (1) The choice of a competitive antagonist may not be the best option because increases in endogenously released glutamate would displace the antagonist and activate NMDA receptors. (2) Pertinent to this idea is the fact that the culture medium was changed every day, which leaves ample time for glutamate turnover and buildup. (3) If such a buildup occurs, the D-AP-5 concentration that was used $(40 \mu \mathrm{M})$ may not have been sufficient to block NMDA receptors effectively (see, e.g., Fig. 4B, Table 1). For instance, Novelli et al. (1988) used 1 mM D-AP-5 to block toxicity elicited by $100 \mu \mathrm{M}$ glutamate or NMDA. Another surprising finding in the study of Del Río et al. (1996) is the fact that they were able to prevent CR cell death with 6-cyano-7-nitroquinoxaline-2,3-dione (CNQX), an antagonist of AMPA receptors. In view of the weak responsiveness of CR cells to AMPA receptor stimulation (Schwartz et al., 1998; J.-M. Mienville, unpublished data), it is possible that this effect was mediated indirectly, as it was with TTX, via the inhibition of glutamatergic cells in the explant.

We have attempted to verify our "NMDA hypothesis" of CR cell death via in vivo treatment with dizocilpine. Although the protocol that uses $0.5 \mathrm{mg} / \mathrm{kg}$ clearly provided protection, we cannot rule out a nonspecific effect mediated via growth retardation and disruption of normal genetic programs. On the other hand, a protocol $(0.1 \mathrm{mg} / \mathrm{kg})$ that did not seem to interfere drastically with development failed to protect CR cells, which we may interpret as incomplete blockade of NMDA receptors. The fact that animals with genetically deleted (knock-out) NMDA receptors die perinatally (Katz, 1994) clearly points to the necessity of using in vitro models to test the influence of NMDA receptor blockade on various parameters. Currently, we are implementing a telencephalic explant culture in which we will test the effects of dizocilpine blockade of NMDA receptors on CR cell survival.

\section{REFERENCES}

Alberts B, Bray D, Lewis J, Raff M, Roberts K, Watson JD (1994) Molecular biology of the cell. New York: Garland.

Blanton MG, LoTurco JJ, Kriegstein AR (1990) Endogenous neurotransmitter activates $N$-methyl-D-aspartate receptors on differentiating neurons in embryonic cortex. Proc Natl Acad Sci USA 87:8027-8030.

Choi DW (1988) Glutamate neurotoxicity and diseases of the nervous system. Neuron 1:623-634.

Colquhoun D, Ogden DC (1988) Activation of ion channels in the frog end-plate by high concentrations of acetylcholine. J Physiol (Lond) 395:131-159.

Crill WE (1996) Persistent sodium current in mammalian central neurons. Annu Rev Physiol 58:349-362.

D'Arcangelo G, Miao GG, Chen S-C, Soares HD, Morgan JI, Curran T (1995) A protein related to extracellular matrix proteins deleted in the mouse mutant reeler. Nature 374:719-723.

De Bergeyck V, Nakajima K, Lambert de Rouvroit C, Naerhuyzen B, Goffinet AM, Miyata T, Ogawa M, Mikoshiba K (1997) A truncated Reelin protein is produced but not secreted in the "Orleans" reeler mutation (Reln ${ }^{\text {rl-Orl }}$ ). Brain Res Mol Brain Res 50:85-90.

Del Río JA, Martinez A, Montserrat F, Auladell C, Soriano E (1995) Glutamate-like immunoreactivity and fate of Cajal-Retzius cells in the murine cortex as identified with calretinin antibody. Cereb Cortex $1: 13-21$

Del Río JA, Heimrich B, Super H, Borrell V, Frotscher V, Soriano E (1996) Differential survival of Cajal-Retzius cells in organotypic cultures of hippocampus and neocortex. J Neurosci 16:6896-6907.

Derer P, Derer M (1990) Cajal-Retzius cell ontogenesis and death in mouse brain visualized with horseradish peroxidase and electron microscopy. Neuroscience 36:839-856.

Derer P, Derer M (1992) Development of Cajal-Retzius cells in vivo and in vitro. In: Development of the central nervous system in vertebrates (Sharma SC, Goffinet AM, eds), pp 113-129. New York: Plenum.

Edwards FA, Konnerth A, Sakmann B, Takahashi T (1989) A thin slice preparation for patch-clamp recordings from neurones of the mammalian central nervous system. Pflügers Arch 414:600-612.

Gorter JA, Titulaer M, Bos NPA, Huisman E (1991) Chronic neonatal MK-801 administration leads to a long-lasting increase in seizure sensitivity during the early stages of hippocampal kindling. Neurosci Lett 134:29-32.

Gould E, Cameron HA, McEwen BS (1994) Blockade of NMDA receptors increases cell death and birth in the developing rat dentate gyrus. J Comp Neurol 340:551-565.

Heinemann SH, Conti F (1992) Nonstationary noise analysis and application to patch-clamp recordings. In: Methods in enzymology (Abelson, JN, Simon MI, eds), Vol 207, Ion channels (Rudy B, Iverson LE, eds), pp 131-148. San Diego: Academic.

Hestrin S, Armstrong WE (1996) Morphology and physiology of cortical neurons in layer I. J Neurosci 16:5290-5300.

Huntley GW, Jones EG (1990) Cajal-Retzius neurons in developing monkey neocortex show immunoreactivity for calcium binding proteins. J Neurocytol 19:200-212.

Jacobson M (1991) Developmental neurobiology. New York: Plenum.

Jahr CE, Stevens CF (1987) Glutamate activates multiple single channel conductances in hippocampal neurons. Nature 325:522-528.

Johnson JL (1978) The excitant amino acids glutamic and aspartic acid as transmitter candidates in the vertebrate central nervous system. Prog Neurobiol 10:155-202.

Katz LC (1994) Somatosensory development. A new level of refinement. Curr Biol 4:831-834.

Kim HG, Fox D, Connors BW (1995) Properties of excitatory synaptic events in neurons of primary somatosensory cortex of neonatal rats. Cereb Cortex 5:148-157.

Lerma J, Herranz AS, Herreras O, Abraira V, Martín del Río R (1986) In vivo determination of extracellular concentration of amino acids in 
the rat hippocampus. A method based on brain dialysis and computerized analysis. Brain Res 384:145-155.

LoTurco JJ, Blanton MG, Kriegstein AR (1991) Initial expression and endogenous activation of NMDA channels in early neocortical development. J Neurosci 11:792-799.

Marín-Padilla M (1998) Cajal-Retzius cells and the development of the neocortex. Trends Neurosci 21:64-71.

Mayer ML, Westbrook GL, Guthrie PB (1984) Voltage-dependent block by $\mathrm{Mg}^{2+}$ of NMDA responses in spinal cord neurones. Nature 309:261-263.

Mayer ML, Westbrook GL, Vyklicky Jr L (1988) Sites of antagonist action on $\mathrm{N}$-methyl-D-aspartic acid receptors studied using fluctuation analysis and a rapid perfusion technique. J Neurophysiol 60:645-663.

McBain CJ, Mayer ML (1994) N-methyl-D-aspartic acid receptor structure and function. Physiol Rev 74:723-760.

McDonald JW, Johnston MV (1990) Physiological and pathophysiological roles of excitatory amino acids during central nervous system development. Brain Res Brain Res Rev 15:41-70.

Mienville J-M (1998a) Low resting potential and upregulation of NMDA receptors: a possible mechanism for Cajal-Retzius cell death? Soc Neurosci Abstr 24:274.

Mienville J-M (1998b) Persistent depolarizing action of GABA in rat Cajal-Retzius cells. J Physiol (Lond) 512:809-817.

Mienville J-M, Barker JL (1997) Potassium current expression during prenatal corticogenesis in the rat. Neuroscience 81:163-172.

Mienville J-M, Lange GD, Barker JL (1994) Reciprocal expression of cell-cell coupling and voltage-dependent Na current during embryogenesis of rat telencephalon. Dev Brain Res 77:89-95.

Momiyama A, Feldmeyer D, Cull-Candy SG (1996) Identification of a native low-conductance NMDA channel with reduced sensitivity to $\mathrm{Mg}^{2+}$ in rat central neurones. J Physiol (Lond) 494:479-492.

Monyer H, Burnashev N, Laurie DJ, Sakmann B, Seeburg PH (1994) Developmental and regional expression in the rat brain and functional properties of four NMDA receptors. Neuron 12:529-540.

Novelli A, Reilly JA, Lysko PG, Henneberry RC (1988) Glutamate becomes neurotoxic via the $N$-methyl-D-aspartate receptor when intracellular energy levels are reduced. Brain Res 451:205-212.

Nowak L, Bregestovski P, Ascher P, Herbet A, Prochiantz A (1984) Magnesium gates glutamate-activated channels in mouse central neurones. Nature 307:462-465.

Oppenheim RW (1991) Cell death during development of the nervous system. Annu Rev Neurosci 14:453-501.
Pesold C, Impagnatiello F, Pisu MG, Uzunov DP, Costa E, Guidotti A, Caruncho HJ (1998) Reelin is preferentially expressed in neurons synthesizing $\gamma$-aminobutyric acid in cortex and hippocampus of adult rats. Proc Natl Acad Sci USA 95:3221-3226.

Pesold C, Liu WS, Guidotti A, Costa E, Caruncho HJ (1999) Cortical bitufted, horizontal and Martinotti cells preferentially express and secrete reelin into perineuronal nets non-synaptically modulating gene expression. Proc Natl Acad Sci USA, in press.

Rakic P, Caviness Jr VS (1995) Cortical development: view from neurological mutants two decades later. Neuron 14:1101-1104.

Ramoa AS, McCormick DA (1994) Developmental changes in electrophysiological properties of LGNd neurons during reorganization of retinogeniculate connections. J Neurosci 14:2089-2097.

Ramón y Cajál S (1891) Sur la structure de l'écorce cérébrale de quelques mammifères. Cellule 7:125-176.

Sah P, Hestrin S, Nicoll RA (1989) Tonic activation of NMDA receptors by ambient glutamate enhances excitability of neurons. Science 246:815-818.

Schiffmann SN, Bernier B, Goffinet AM (1997) Reelin mRNA expression during mouse brain development. Eur J Neurosci 9:1055-1071.

Schwartz TH, Rabinowitz D, Unni V, Kumar VS, Smetters DK, Tsiola A, Yuste R (1998) Networks of coactive neurons in developing layer 1. Neuron 20:541-542.

Sheng M, Cummings J, Roldan LA, Jan YN, Jan LY (1994) Changing subunit composition of heteromeric NMDA receptors during development of rat cortex. Nature 368:144-147.

Stern P, Behe P, Schoepfer R, Colquhoun D (1992) Single-channel conductances of NMDA receptors expressed from cloned cDNAs: comparison with native receptors. Proc R Soc Lond [Biol] 250:271-277.

Sweadner KJ (1989) Isozymes of the $\mathrm{Na}^{+} / \mathrm{K}^{+}$-ATPase. Biochim Biophys Acta 988:185-220.

Westbrook GL, Mayer ML, Namboodiri MAA, Neale JH (1986) High concentrations of $N$-acetylaspartylglutamate (NAAG) selectively activate NMDA receptors on mouse spinal cord neurons in cell culture. J Neurosci 6:3385-3392.

Williams K (1993) Ifenprodil discriminates subtypes of the $N$-methyl-Daspartate receptor: selectivity and mechanisms at recombinant heteromeric receptors. Mol Pharmacol 44:851-859.

Zhou FM, Hablitz JJ (1996) Postnatal development of membrane properties of layer I neurons in rat neocortex. J Neurosci 16:1131-1139. 